\title{
Predator-specific growth-selective predation on larval Japanese anchovy Engraulis japonicus
}

\author{
Akinori Takasuka ${ }^{1, *}$, Ichiro Aoki ${ }^{2}$, Yoshioki Oozeki ${ }^{1}$ \\ ${ }^{1}$ National Research Institute of Fisheries Science, Fisheries Research Agency, 2-12-4 Fukuura, Kanazawa, Yokohama, \\ Kanagawa 236-8648, Japan \\ ${ }^{2}$ Department of Aquatic Bioscience, Graduate School of Agricultural and Life Sciences, The University of Tokyo, \\ 1-1-1 Yayoi, Bunkyo, Tokyo 113-8657, Japan
}

\begin{abstract}
Predator-specific growth-selective predation on larval Japanese anchovy Engraulis japonicus was demonstrated by comparing growth rates between the larvae ingested by predators and the larvae from the corresponding original populations through otolith microstructure analysis, based on original data and reanalyzed data from previous studies. Ingested larvae from the stomachs of small pelagic predators (juvenile Japanese anchovy, round herring Etrumeus teres, jack mackerel Trachurus japonicus and white croaker Pennahia argentatus) had significantly lower growth rates than the larvae from the original populations in general. For large piscivorous predators (sea bass Lateolabrax japonicus, greater amberjack Seriola dumerili and skipjack tuna Katsuwonus pelamis), no measurable differences in the growth rates were observed between ingested larvae and larvae from the original populations. Small pelagic fish were therefore identified as growth-selective predators, whereas large piscivorous fish were identified as non-growth-selective predators. Exponential declines in the relative predation mortalities of larvae with higher growth rates suggest the potential for growth rate to exert a great effect on recruitment variability. However, the predator field would regulate selection for growth characteristics of survivors.
\end{abstract}

KEY WORDS: Growth-selective predation hypothesis · Growth rate · Otolith · Early life stage · Japanese anchovy $\cdot$ Relative predation mortality $\cdot$ Optimal foraging theory

Resale or republication not permitted without written consent of the publisher

\section{INTRODUCTION}

Fish experience severe challenges to survival during their early life stages. Growth rates represent survival potential during these stages, playing a key role in survival dynamics. The paradigm that faster-growing individuals are more likely to survive has emerged through numerous studies (Meekan \& Fortier 1996, Hare \& Cowen 1997, Baumann et al. 2003, Takasuka et al. 2003, Takahashi \& Watanabe 2004, Tanaka et al. 2006), and led to various field study designs (Shoji \& Tanaka 2006, Takasuka \& Aoki 2006, Robert et al. 2007, Takasuka et al. 2007), although there have been some conflicting observations (Litvak \& Leggett 1992, Lankford et al. 2001, Munch \& Conover 2003). Ander- son (1988) concluded that the theory linking growth rate and mortality provides a rational framework, but that the relationship remains to be quantified. To clarify how and to what extent growth rates regulate survival, the functional mechanisms of the 'growthsurvival' paradigm need to be scrutinized at finer scales (Hare \& Cowen 1997, Searcy \& Sponaugle 2001).

The growth-survival paradigm has been explained by size and time. The size-based concept, known as the bigger-is-better hypothesis (Miller et al. 1988), assumes survival advantages of larger somatic size of faster-growing individuals, although several studies concluded that bigger is not always better (Leggett \& DeBlois 1994). The time-based idea is termed the 
stage-duration hypothesis (Chambers \& Leggett 1987 , Houde 1987, 1989) and assumes that mortality rate decreases markedly with developmental stage. If a higher growth rate accelerates the timing of metamorphosis, faster-growing individuals will experience a much lower cumulative mortality rate during the larval stage. In these concepts, however, growth rates are translated into size or time and thus are indirectly linked to survival. Furthermore, no direct evidence has linked growth rate to predation, despite predation being recognized as the major source of mortality (Bailey \& Houde 1989). These issues emerged because previous field tests focused solely on the characteristics of the survivors (references in Takasuka et al. 2003).

Takasuka et al. (2003) instead focused on the characteristics of larvae actually ingested by predators. Growth rates were compared between larval Japanese anchovy Engraulis japonicus from the stomachs of predators and the larvae from the original populations. As a consequence, the growth-selective predation hypothesis was proposed, which states that slowergrowing individuals are more vulnerable to predation than their faster-growing conspecifics, even if they are of the same size. This hypothesis was also supported by the characteristics of the survivors (Takasuka et al. 2004a). However, it was suggested that the occurrence of growth-selective predation could differ among predatory species (Takasuka et al. 2003, 2004b). Predator specificity, if it exists, could markedly influence phenotypic selection and thus needs clarification if growth rates are to be used as a predictor of recruitment.

The present study shows predator-specific growthselective predation on larval Japanese anchovy, based on original data and reanalyzed data from previous studies (Takasuka et al. 2003, 2004a,b). Through otolith microstructure analysis, growth rates and somatic sizes were compared between larvae from the stomachs of different predatory species and larvae from the original populations. Furthermore, changes in relative predation mortality with varying growth rates were estimated to quantify the potential role of growth-selective predation in survival dynamics.

\section{MATERIALS AND METHODS}

We conducted field collections of larval anchovy and predators in Sagami Bay, Japan, in 2001 and reanalyzed data from the previous studies by Takasuka et al. (2003, 2004b) (Table 1). Collection and quantitative methods from all studies were performed identically, unless otherwise noted.

Larval anchovy and their fish predators were captured simultaneously by the same tows of a commer- cial trawl with a cod-end mesh size of $2.3 \mathrm{~mm}$. The trawl was towed for 5 to 10 min several times after sunrise. Our same-tow sampling targeted dense larval shoals and predators attacking them in shallow $(<10 \mathrm{~m})$ areas. In Takasuka et al. (2003), sampling was conducted in Sagami Bay from 28 October to 4 November 2000 (Sample I) and on 23 November 2000 (Sample II). We added original samples collected in Sagami Bay from 1 to 9 July 2001 (Sample III), on 18 July 2001 (Sample IV) and from 6 to 8 November (Sample V) 2001. In Takasuka et al. (2004b), offshore sampling was conducted in the western North Pacific; larval and juvenile anchovy were captured by the same tow of a frame-type trawl with an $8 \mathrm{~mm}$ stretch mesh on 11 June 1997 (Sample VI), and larval anchovy and skipjack tuna Katsuwonus pelamis were captured concurrently using a neuston net with a mesh size of $0.45 \mathrm{~mm}$ and trolling lines, respectively, on 15 May 2000 (Sample VII). More details of sampling methods and location are described in the respective source papers.

Larval anchovy were captured simultaneously with the predators (original larvae) and were taken from the stomach contents of dissected predators (ingested larvae). Using the same-tow or concurrent sampling of larvae and predators, we assumed that the ingested larvae and original larvae originated from the same populations. The standard length (SL) of each original larva was measured directly, while that of each ingested larva was estimated from otolith sizes, except for individuals in an undigested condition. The extent of digestion of the ingested larvae was ranked as follows. Rank 1: fresh or having partial digestion of the integument; Rank 2: partial digestion of muscular tissue $(<\mathrm{ca} .75 \%$ by sight); Rank 3: most of the muscular tissue digested.

Sagittal otoliths were extracted from both ingested larvae and original larvae. Maximum otolith radius (OR) and each daily growth increment width were measured to the nearest $0.1 \mu \mathrm{m}$ along a measurement transect set from the nucleus to the outermost margin, with a transmitting light microscope equipped with a video camera connected to a computer and monitor. The relationships between SL and OR were expressed as allometric formulae for all samples of original larvae $\left(0.786 \leq \mathrm{r}^{2} \leq 0.930, \mathrm{p}<0.001\right)$. The SL of each ingested larvae was estimated from its OR, based on the OR-SL relationships from the corresponding original larvae. This SL estimation procedure was previously validated to prevent serious biases in size and growth comparisons (Takasuka et al. 2003).

Daily growth-rate history was back-calculated at the individual level by the biological intercept method (Campana 1990, Campana \& Jones 1992), based on an allometric formula determined for each larva. The SL 
Table 1. Engraulis japonicus. Comparison of standard length (SL; mean $\pm \mathrm{SD}$ ) and recent $5 \mathrm{~d}$ growth rate (GR; mean $\pm \mathrm{SD}$ ) between larvae from stomach contents of each predatory fish species (ingested larvae) and from the original populations (original larvae). SL or fork length (FL) is indicated in parentheses for each predatory species. Numbers of individuals are indicated for predators $(\mathrm{N})$, predators whose stomachs contained larvae $\left(\mathrm{N}^{\prime}\right)$, ingested larvae in the stomachs $(\mathrm{n})$, ingested larvae available for sagittal otolith microstructure analysis $\left(\mathrm{n}^{\prime}\right)$ and original larvae $\left(\mathrm{n}^{\prime \prime}\right)$. If the regression of growth rates on SL for the original larvae and differences in SL between the ingested larvae and original larvae were both significant, growth rates were compared within the overlapped range of SL between the 2 groups. Larger and Smaller: SL of the ingested larvae was larger/smaller than those of the original larvae; Higher and Lower: growth rates of the ingested larvae were higher/lower than those of the original larvae. Samples I and II were derived from Takasuka et al. (2003); Samples VI and VII were derived from Takasuka et al. (2004b). Samples III, IV and V represent original data described herein. ${ }^{*} \mathrm{p}<0.05,{ }^{* *} \mathrm{p}<0.01$, ${ }^{\mathrm{a}}$ Student's $t$-test, ${ }^{b}$ Welch's $t$-test or cMann-Whitney's $U$-test

\begin{tabular}{|c|c|c|c|c|c|c|c|c|}
\hline \multirow{2}{*}{$\begin{array}{l}\text { Sample (date of capture) } \\
\text { Ingested larvae (by predator) } \\
\text { or original larvae }\end{array}$} & \multirow{2}{*}{$\begin{array}{l}\text { Predator } \\
\mathrm{N}\left(\mathrm{N}^{\prime}\right)\end{array}$} & \multicolumn{3}{|c|}{ Larvae } & \multirow{2}{*}{$\begin{array}{r}\text { SL (mm) } \\
\text { (range) }\end{array}$} & \multirow{2}{*}{$\begin{array}{l}\mathrm{GR}\left(\mathrm{mm} \mathrm{d}^{-1}\right) \\
\quad \text { (range) }\end{array}$} & \multicolumn{2}{|c|}{ Comparison } \\
\hline & & $\mathrm{n}$ & $\mathrm{n}^{\prime}$ & $\mathrm{n} "$ & & & SL & GR \\
\hline \multicolumn{9}{|l|}{ Sample I (28 Oct-4 Nov ‘00) } \\
\hline Original larvae & - & - & - & 120 & $\begin{array}{c}20.3 \pm 3.3 \\
(14.0-30.0)\end{array}$ & $\begin{array}{l}0.44 \pm 0.11 \\
(0.24-0.80)\end{array}$ & - & - \\
\hline $\begin{array}{l}\text { Japanese anchovy } \\
(67-70 \mathrm{~mm} \mathrm{SL})\end{array}$ & $2(2)$ & 24 & 9 & - & $\begin{array}{l}16.5 \pm 1.5 \\
(14.8-19.5)\end{array}$ & $\begin{array}{l}0.33 \pm 0.05 \\
(0.26-0.44)\end{array}$ & Smaller*b & Lower*a \\
\hline $\begin{array}{l}\text { Japanese jack mackerel } \\
\text { (98-138 mm FL) }\end{array}$ & $12(1)$ & 7 & 6 & - & $\begin{array}{c}17.9 \pm 1.5 \\
(15.8-19.9)\end{array}$ & $\begin{array}{l}0.33 \pm 0.06 \\
(0.24-0.40)\end{array}$ & $\mathrm{NS}^{\mathrm{a}}$ & Lower*a \\
\hline $\begin{array}{l}\text { White croaker } \\
(123-128 \mathrm{~mm} \text { SL) }\end{array}$ & $2(2)$ & 15 & 13 & - & $\begin{array}{l}21.3 \pm 2.6 \\
(16.4-26.0)\end{array}$ & $\begin{array}{l}0.37 \pm 0.06 \\
(0.27-0.47)\end{array}$ & $\mathrm{NS}^{\mathrm{a}}$ & Lower**b \\
\hline $\begin{array}{l}\text { Japanese sea bass } \\
(202-210 \mathrm{~mm} \mathrm{SL})\end{array}$ & $2(2)$ & 12 & 4 & - & $\begin{array}{l}24.1 \pm 1.9 \\
(21.4-25.7)\end{array}$ & $\begin{array}{l}0.44 \pm 0.17 \\
(0.19-0.55)\end{array}$ & Larger**c & $\mathrm{NS}^{\mathrm{a}}$ \\
\hline \multicolumn{9}{|l|}{ Sample II (23 Nov `00) } \\
\hline Original larvae & - & - & - & 120 & $\begin{array}{l}21.8 \pm 1.9 \\
(18.7-28.6)\end{array}$ & $\begin{array}{l}0.33 \pm 0.07 \\
(0.20-0.55)\end{array}$ & - & - \\
\hline $\begin{array}{l}\text { Pacific round herring } \\
\text { (134-148 mm SL) }\end{array}$ & $3(3)$ & 60 & 40 & - & $\begin{array}{l}21.6 \pm 2.3 \\
(17.6-28.5)\end{array}$ & $\begin{array}{l}0.28 \pm 0.04 \\
(0.14-0.38)\end{array}$ & $\mathrm{NS}^{\mathrm{a}}$ & Lower $*$ b \\
\hline \multicolumn{9}{|l|}{ Sample III (1-9 Jul `01) } \\
\hline Original larvae & - & - & - & 120 & $\begin{array}{c}25.4 \pm 3.6 \\
(15.6-33.2)\end{array}$ & $\begin{array}{l}0.44 \pm 0.08 \\
(0.27-0.74)\end{array}$ & - & - \\
\hline $\begin{array}{l}\text { Japanese jack mackerel } \\
\text { (93-167 mm FL) }\end{array}$ & $15(7)$ & 21 & 16 & - & $\begin{array}{c}25.2 \pm 5.2 \\
(15.2-34.3)\end{array}$ & $\begin{array}{l}0.39 \pm 0.08 \\
(0.25-0.58)\end{array}$ & $\mathrm{NS}^{\mathrm{b}}$ & Lower*a \\
\hline $\begin{array}{l}\text { Greater amberjack } \\
(135-199 \mathrm{~mm} \text { FL })\end{array}$ & $2(2)$ & 28 & 15 & - & $\begin{array}{l}25.5 \pm 2.3 \\
(20.7-29.3)\end{array}$ & $\begin{array}{l}0.41 \pm 0.07 \\
(0.30-0.52)\end{array}$ & $\mathrm{NS}^{\mathrm{a}}$ & $\mathrm{NS}^{\mathrm{a}}$ \\
\hline \multicolumn{9}{|l|}{ Sample IV (18 Jul `01) } \\
\hline Original larvae & - & - & - & 120 & $\begin{array}{c}24.7 \pm 3.5 \\
(16.1-32.4)\end{array}$ & $\begin{array}{l}0.42 \pm 0.08 \\
(0.24-0.65)\end{array}$ & - & - \\
\hline $\begin{array}{l}\text { Pacific round herring } \\
(71-86 \mathrm{~mm} \text { SL) }\end{array}$ & $5(5)$ & 53 & 30 & - & $\begin{array}{l}19.8 \pm 2.5 \\
(15.0-26.4)\end{array}$ & $\begin{array}{l}0.42 \pm 0.08 \\
(0.28-0.61)\end{array}$ & Smaller**c & $\mathrm{NS}^{\mathrm{c}}$ \\
\hline $\begin{array}{l}\text { Japanese jack mackerel } \\
(114-198 \mathrm{~mm} \text { FL) }\end{array}$ & $4(3)$ & 33 & 27 & - & $\begin{array}{l}23.7 \pm 3.3 \\
(16.5-28.3)\end{array}$ & $\begin{array}{l}0.39 \pm 0.08 \\
(0.27-0.62)\end{array}$ & $\mathrm{NS}^{\mathrm{a}}$ & Lower*a \\
\hline \multicolumn{9}{|l|}{ Sample V (6-8 Nov ‘01) } \\
\hline Original larvae & - & - & - & 120 & $\begin{array}{l}26.2 \pm 2.3 \\
(20.4-31.4)\end{array}$ & $\begin{array}{l}0.43 \pm 0.07 \\
(0.29-0.62)\end{array}$ & - & - \\
\hline $\begin{array}{l}\text { Pacific round herring } \\
(112-132 \mathrm{~mm} \text { SL) }\end{array}$ & $15(15)$ & 288 & 67 & - & $\begin{array}{l}25.2 \pm 2.6 \\
(19.6-32.0)\end{array}$ & $\begin{array}{l}0.40 \pm 0.07 \\
(0.28-0.59)\end{array}$ & Smaller**a & Lower**a \\
\hline $\begin{array}{l}\text { Japanese jack mackerel } \\
(127-154 \mathrm{~mm} \text { FL) }\end{array}$ & $6(3)$ & 26 & 19 & - & $\begin{array}{l}24.3 \pm 1.5 \\
(22.0-27.0)\end{array}$ & $\begin{array}{l}0.39 \pm 0.06 \\
(0.31-0.53)\end{array}$ & Smaller**a & Lower**a \\
\hline \multicolumn{9}{|l|}{ Sample VI (11 Jun ‘97) } \\
\hline Original larvae & - & - & - & 100 & $\begin{array}{c}18.9 \pm 3.1 \\
(13.1-31.1)\end{array}$ & $\begin{array}{l}0.57 \pm 0.12 \\
(0.34-0.99)\end{array}$ & - & - \\
\hline $\begin{array}{l}\text { Japanese anchovy } \\
\text { (36-61 mm SL) }\end{array}$ & $120(31)$ & 85 & 33 & - & $\begin{array}{l}17.5 \pm 1.4 \\
(13.6-20.2)\end{array}$ & $\begin{array}{l}0.50 \pm 0.07 \\
(0.38-0.63)\end{array}$ & Smaller**c & Lower**b \\
\hline \multicolumn{9}{|l|}{ Sample VII (15 May ‘00) } \\
\hline Original larvae & - & - & - & 47 & $\begin{array}{c}22.0 \pm 3.1 \\
(14.4-27.4)\end{array}$ & $\begin{array}{l}0.48 \pm 0.08 \\
(0.26-0.61)\end{array}$ & - & - \\
\hline $\begin{array}{l}\text { Skipjack tuna } \\
(450-540 \mathrm{~mm} \text { FL) }\end{array}$ & $9(7)$ & 59 & 12 & - & $\begin{array}{l}23.9 \pm 1.2 \\
(22.2-26.2)\end{array}$ & $\begin{array}{l}0.50 \pm 0.08 \\
(0.35-0.64)\end{array}$ & Larger $^{* c}$ & $\mathrm{NS}^{\mathrm{a}}$ \\
\hline Total & $197(83)$ & 711 & 291 & 747 & & & & \\
\hline
\end{tabular}


at the first ring deposition (i.e. biological intercept) was fixed at $5.6 \mathrm{~mm}$. A recent $5 \mathrm{~d}$ mean growth rate $\left(\mathrm{mm} \mathrm{d}^{-1}\right)$ directly before capture or predation was adopted as a proxy for survival potential, as recent growth rates reflect conditions that affect selective mortality (Oozeki et al. 2004, Takasuka et al. 2004b). To test size- and growth-selective predation mortalities, SL at the time of capture or predation and recent $5 \mathrm{~d}$ mean growth rates were compared between the ingested larvae and corresponding original larvae by Student's $t$-test, Welch's $t$-test or Mann-Whitney's $U$-test, depending on the results of tests of normality and homogeneity for each pair. If growth rates are related to somatic sizes, including the overall size range could lead to biases in growth comparisons under any significant size-selective predation. When growth rates were significantly related to SL for the original larvae and SL differed significantly between ingested and original larvae, we compared the growth rates of the original and ingested larvae whose SL range overlapped to reduce a possibility of such biases and discriminate size- and growth-selections.

The intensities of selection for size or growth rate were quantified by comparing the relative frequency distributions of estimated size or growth rate between the survivors and the original population (i.e. survival ratio) (Healey 1982, Hovenkamp 1992, Meekan \& Fortier 1996). Since the present study focused on the characteristics of ingested larvae versus original larvae, we calculated the predation mortality ratio (PMR) as a proxy for relative predation mortality: PMR = $F_{\text {ingested }} / F_{\text {original, }}$ where $F_{\text {ingested }}$ and $F_{\text {original }}$ are relative frequencies of each class of recent $5 \mathrm{~d}$ mean growth rate (interval: $0.05 \mathrm{~mm} \mathrm{~d}^{-1}$ ) for the ingested larvae and original larvae, respectively.

\section{RESULTS}

Pacific round herring Etrumeus teres, Japanese jack mackerel Trachurus japonicus, white croaker Argyrosomus argentatus, Japanese sea bass Lateolabrax japonicus, greater amberjack Seriola dumerili and skipjack tuna Katsuwonus pelamis were found to be predators of larval anchovy (Table 1). Furthermore, juvenile Japanese anchovy also preyed on larvae of their own species. A total of 711 larval anchovy were collected from the stomach contents of 83 (of 197) individual predators; sagittal otoliths of 291 larvae were available for analysis. SL was estimated for 255 ingested larvae and directly measured for the remaining 36 ingested larvae. The ingested larvae were digested to varying degrees. For the 3 original samples (Samples III, IV and V), the ingested larvae with otoliths available were classified into Rank $1(\mathrm{n}=21)$,
Rank $2(n=104)$ and Rank $3(n=49)$. No significant differences were found in growth rates among digestion ranks (where sample sizes allowed comparison), at least within each sample or within the ingested larvae from round herring of Sample V (ANOVA, $p>0.05$ ). As such, we pooled the ingested larvae within each sample regardless of the extent of digestion.

The ingested larvae were compared with their corresponding original larvae in terms of SL for each predatory species (Table 1). The SL of the ingested larvae was significantly smaller than the original larvae for juvenile anchovy (Samples I and VI), round herring (Samples IV and V) and Japanese jack mackerel (Sample V). By contrast, the ingested larvae from the stomachs of sea bass and skipjack tuna had larger SL than the original larvae (Samples I and VII). No significant differences were found between ingested larvae and original larvae for round herring from Sample II, jack mackerel from Samples I, III and IV, white croaker from Sample I and greater amberjack from Sample III.

Recent 5 d mean growth rates were positively related with SL for the original larvae from Samples I, II, VI and VII (Fig. 1; linear regression analysis, $0.066 \leq$ $\mathrm{r}^{2} \leq 0.295, \mathrm{p}<0.01$ ), but this was not the case with the original larvae from Samples III, IV and V $\left(0.001 \leq \mathrm{r}^{2} \leq\right.$ $0.014, \mathrm{p}>0.05)$. Thus, the original larvae whose SL range overlapped with the SL of the ingested larvae were used for growth comparisons for anchovy and sea bass from Sample I, juvenile anchovy from Sample VI and skipjack tuna from Sample VII. For Samples III, IV and $V$, size ranges were not considered in growth comparisons, even when SL differed between ingested larvae and original larvae.

The growth rates of the ingested larvae were generally lower than those of their corresponding original larvae when compared at the same SL (Fig. 1). Such same-size differences in growth rates were particularly evident for larvae with SL $>20$ to $25 \mathrm{~mm}$. The growth rates of the ingested larvae from juvenile anchovy (Samples I and VI), round herring (Samples II and V), jack mackerel (Samples I, III, IV and V) and white croaker (Sample I) were significantly lower than those of the corresponding original larvae $(p<0.05)$ (Table 1). No differences were found for the ingested larvae from round herring from Sample IV. There were also no significant differences in growth rates between ingested larvae and original larvae for sea bass (Sample I), greater amberjack (Sample III) and skipjack tuna (Sample VII) $(\mathrm{p}>0.05)$.

PMR was calculated for the predatory species that exhibited significant growth-selective predation. In general, PMR declined exponentially with growth rate (Fig. 2). Based on the exponential functions fitted to the PMR versus growth rate, the decline in growth rates 

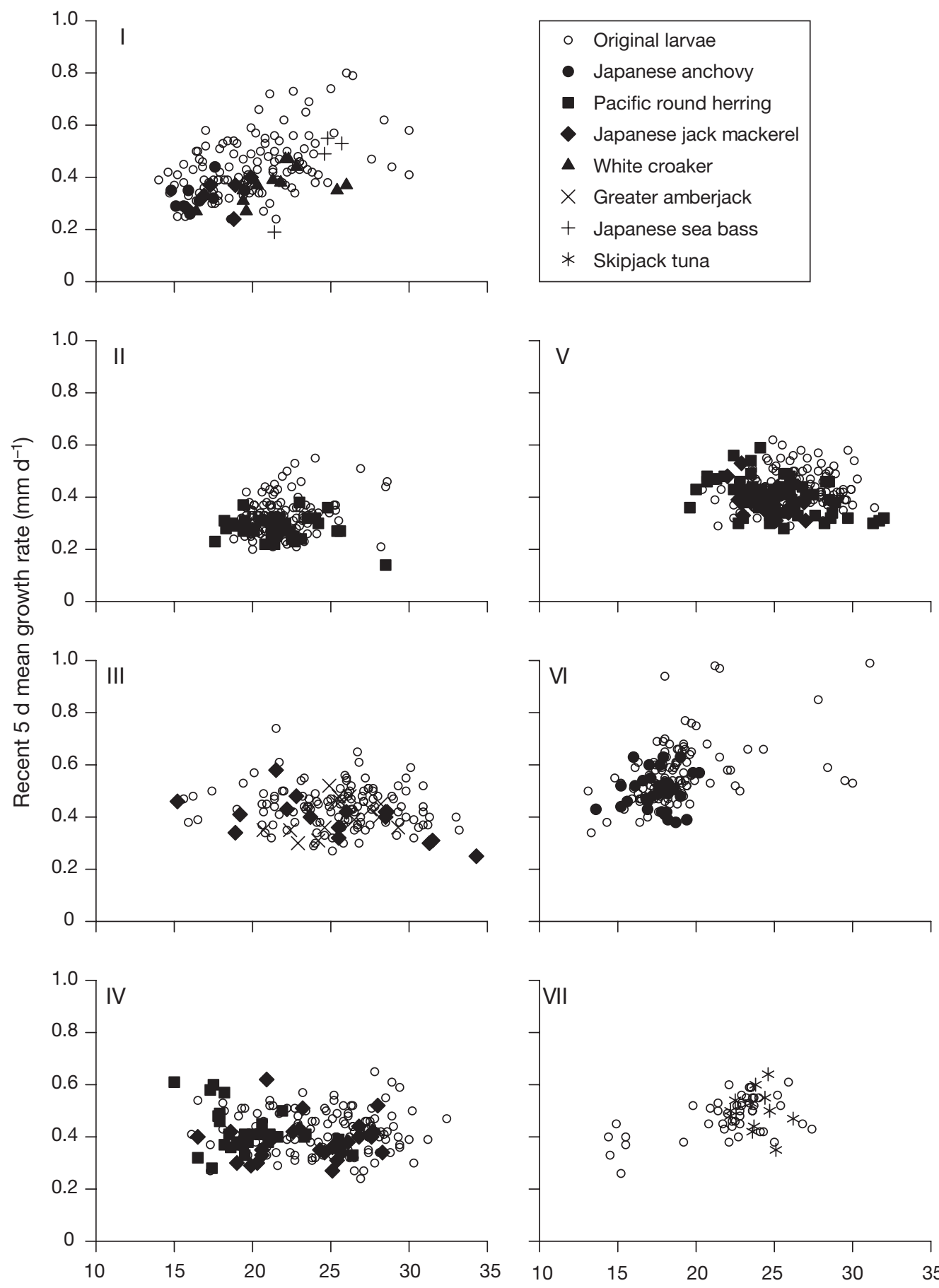

Standard length $(\mathrm{mm})$

Fig. 1. Engraulis japonicus. Recent 5 d mean growth rate on standard length compared between original larvae and ingested larvae (represented by predatory species and original larvae). Sample profiles are summarized in Table 1

from 0.50 to $0.30 \mathrm{~mm} \mathrm{~d}^{-1}$ corresponded to an increase in PMR from 0.21 to 3.43 for juvenile anchovy, jack mackerel and white croaker from Sample I, from 0.38 to 2.24 for jack mackerel from Sample IV and from 0.50 to 2.49 for round herring and jack mackerel from
Sample V. Similarly, as growth rates decreased from 0.40 to $0.20 \mathrm{~mm} \mathrm{~d}^{-1}$ and from 0.70 to $0.40 \mathrm{~mm} \mathrm{~d}^{-1}$, the PMR increased from 0.33 to 3.03 and from 0.33 to 2.28 for round herring from Sample II and juvenile anchovy from Sample VI, respectively. 

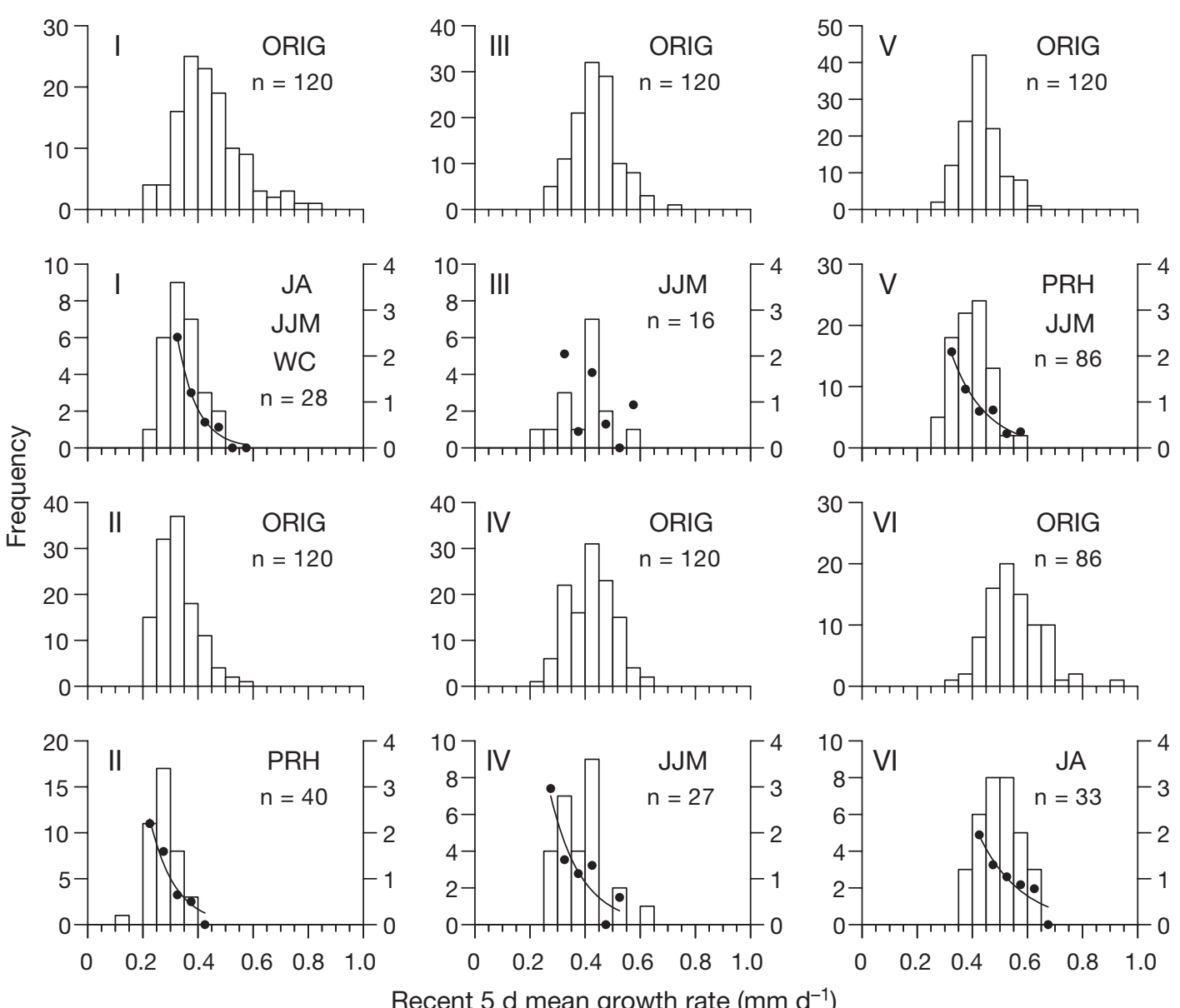

Recent $5 \mathrm{~d}$ mean growth rate $\left(\mathrm{mm} \mathrm{d}^{-1}\right)$

Fig. 2. Engraulis japonicus. Frequency distributions of recent $5 \mathrm{~d}$ mean growth rate compared between ingested larvae and original larvae in conjunction with predation mortality ratios (PMR) of the ingested larvae. Sample profiles are summarized in Table 1. ORIG: original larvae; JA, PRH, JJM and WC: ingested larvae from the stomachs of Japanese anchovy, Pacific round herring, Japanese jack mackerel and white croaker, respectively. Ingested larvae from different predatory species were pooled for Samples I and V. Functions of single exponential decay were fitted to the PRM values (but the infinities and the values at growth rate class with relative frequency of $<0.05$ for the original larvae were excluded). Sample I: $y=234.5 \mathrm{e}^{-14.1 x}\left(\mathrm{r}^{2}=0.988, \mathrm{p}<0.001\right)$; Sample II: $y=27.4 \mathrm{e}^{-11.0 x}\left(\mathrm{r}^{2}=0.948, \mathrm{p}=0.013\right)$; Sample III: not significant $\left(\mathrm{r}^{2}=0.346, \mathrm{p}=0.244\right) ;$ Sample IV: $y=32.4 \mathrm{e}^{-8.9 x}\left(\mathrm{r}^{2}=\right.$ $0.842, \mathrm{p}=0.021)$; Sample V: $y=27.6 \mathrm{e}^{-8.0 x}\left(\mathrm{r}^{2}=0.962, \mathrm{p}=0.001\right)$; Sample VI: $y=30.3 \mathrm{e}^{-6.5 x}\left(\mathrm{r}^{2}=0.884, \mathrm{p}=0.010\right)$

\section{DISCUSSION}

Size-selective predation on larval anchovy and its direction depended on predatory species. Size-selection favored larger larvae for juvenile anchovy, round herring and jack mackerel, and favored smaller larvae for sea bass and skipjack tuna-although in some samples, round herring and jack mackerel showed no size-selection. For the bigger-is-better mechanism to come into effect in the growth-survival paradigm, the assumption of a positive relationship between growth rate and somatic size must be satisfied. If all individuals hatched on the same date, this would be the case. However, in natural populations the individuals of different sizes, ages and growth rates are mixed. No clear relationship between growth rates and sizes was ob- served for 3 of 7 original populations of larval anchovy, indicating that even if size-selection favors larger larvae, it does not always follow that faster-growing larvae have enhanced survivorship.

Predator-specific growth-selective predation was demonstrated through snapshots of prey-predator interactions between larval anchovy and various fish predators in field conditions. Slower-growing larvae were more vulnerable to predation than faster-growing conspecifics when they were attacked by juvenile anchovy, round herring, jack mackerel and white croaker. This growth-selective predation was observed for larvae of the same size and thus was independent of somatic size and stage duration. The link between growth rate and predation could be mediated by physiological condition and the ability for anti-predator 
behaviors (Takasuka et al. 2003). In general, larval behavior is closely related to predation vulnerability (Fuiman \& Magurran 1994, Fuiman et al. 2005). Physiological conditions can affect responses to predator attacks, escape activities (Chick \& Van Den Avyle 2000, Grorud-Colvert \& Sponaugle 2006) and positions in larval shoals (Skajaa et al. 2003). The characteristics-of-survivors approach also has indicated selective removal of individuals with poorer physiological conditions (Searcy \& Sponaugle 2001, Hoey \& McCormick 2004). Slower-growing larvae would have lower potential for anti-predator behaviors and may tend to be isolated from shoals, owing to deteriorated conditions. This inference also explains the possible shifts from random to growth-selective predation mortalities with larval size, since variation in the ability for antipredator behaviors would increase as larvae develop (Skajaa et al. 2003).

Differences in predation mortality among different predator species or types have been shown in experimental studies (Bailey \& Houde 1989, Chick \& Van Den Avyle 2000); however, direct evidence has rarely been obtained in field conditions. The present study revealed that the presence of growth-selective predation on larval anchovy depended on predatory species. In general, juvenile anchovy, round herring, jack mackerel and white croaker ingested slower-growing larvae selectively and were therefore identified as growth-selective predators. In contrast, sea bass, greater amberjack and skipjack tuna ingested larvae almost randomly and were therefore identified as non-growth-selective predators. A distinction between these 2 predator groups lies in their sizes and, perhaps, feeding strategies. The growth-selective predators in this study comprise relatively small pelagic species whose stomachs contained zooplankton such as copepods as alternative prey (data not shown). In contrast, non-growth-selective predators comprise relatively large piscivorous predatory species whose stomachs contained almost exclusively fish larvae and juveniles. Probably because of the different attack performance of predators, faster-growing larvae may be able to escape from small pelagic predator attacks, but not from large piscivorous predators. However, future studies may need to clarify the more dynamic aspects of prey-predator interactions, as the size and feeding ecology of predators shift.

Both the size- and growth-selective predation mechanisms have a similar causal background, since sizeselective mortality is also related to larval activity (Miller et al. 1988). Why do small pelagic predators nonetheless often select for growth rate rather than size? This could be theoretically addressed from the viewpoint of the optimal foraging theory with regard to of predators (Takasuka et al. 2003). The smaller the larva a predator selects, the more easily the predator is able to capture the larva, but the gain of energy is less, since energy provided by the larva is an exponential function of larval size (Fig. 3: solid curves). In sizeselective predation, net profitability for predators will approximate a dome-shaped function of larval size. However, by selecting a larva with a lower growth rate (irrespective of size), a predator minimizes its energy loss because the larva is easier to capture (due to its presumably poorer physiological condition) than a faster-growing larva of comparable size. In growthselective predation, net profitability for predators will therefore be a monotone decreasing function of larval growth rate. Although the relative importance of size and growth rate has yet to be quantified, growth selection was more consistent than size selection within the size and growth ranges of the targeted populations. In reality, a predator does not consciously select a slowergrowing larva; rather it incidentally ingests a slowergrowing larva as a consequence of larval behaviors. However, the mechanism is rational for small pelagic predators. In contrast, large piscivorous predators
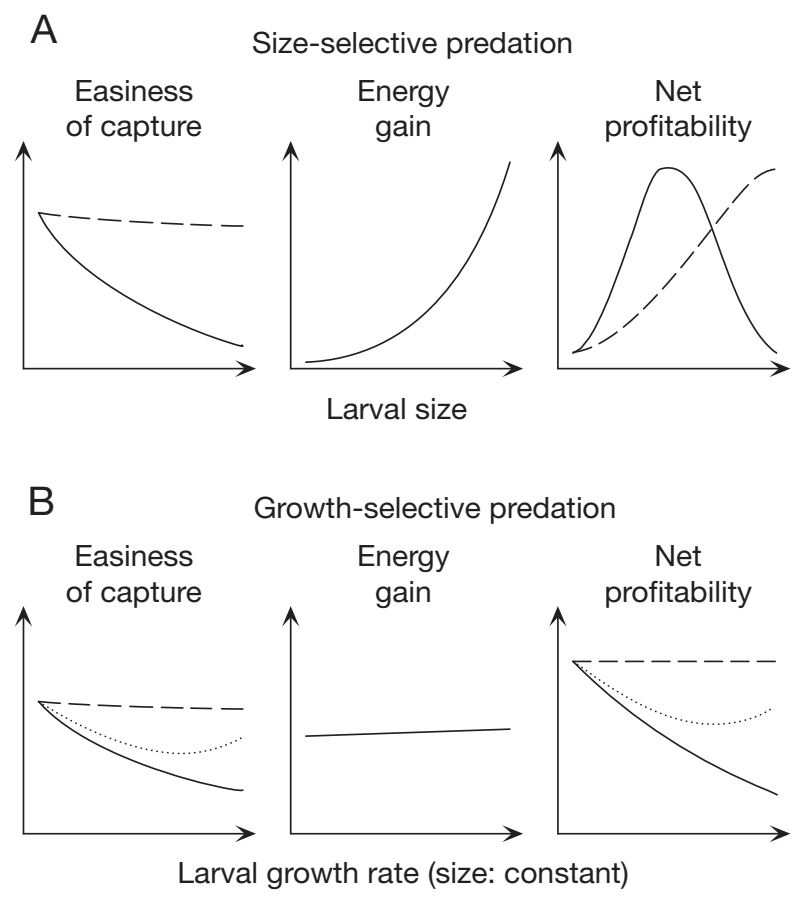

Fig. 3. Engraulis japonicus. Conceptual curves of fitness for predators based on the optimal foraging theory in (A) sizeselective predation (only larval size considered) and (B) growth-selective predation (larval growth rate at the same size is considered). Solid and dashed curves indicate small pelagic predators and large piscivorous predators, respectively, from the present findings for the target populations of larval anchovy; dotted curves indicate an example of other possible patterns deduced from literature. Note that axes are not to be compared quantitatively within a panel or among panels 
would not benefit from easiness of capture of a smaller or slower-growing larva because of their higher attack abilities, leading to non-growth-selection and, maybe, positive size-selection (Fig. 3: dashed curves). Note that predation vulnerability may become more complex if growth rates affect an encounter rate with predators (Bailey \& Houde 1989). Also, if maximized growth rate increases predation susceptibility under an energy and growth trade-off against investment in anti-predator performance (Lankford et al. 2001, Munch \& Conover 2003), the net profitability for small pelagic predators may deviate from a monotone decrease with growth rate (Fig. 3: dotted curves). In any case, the present field tests did not detect any disadvantage to faster-growing larvae.

At present, the stage-duration theory is most compelling to explain the effect of growth rate on survival probability. Houde (1987) showed that a more than 100 -fold fluctuation in survival probabilities could result through cumulative effects of stage duration. In theory, the growth-selective predation mechanism is independent of and synergistic with size- and timebased mechanisms (Takasuka et al. 2003). The observed changes in PMR values with larval growth rates for the growth-selective predators showed that even subtle growth variations could lead to considerable fluctuations in relative predation mortality even through instantaneous events. Every encounter with a growth-selective predator will elevate mortality risk for slower-growing larvae. As such, growth-selective predation would serve as an amplifier in growthsurvival processes during the early life stages in a predator field dominated by growth-selective predators; yet it would be less relevant in a predator field dominated by non-growth-selective predators. Growth rates potentially exert a far greater impact on recruitment variability through synergistic effects of multiple mechanisms than previously expected. However, the predator field would strongly regulate selection for growth characteristics of survivors, and serve as a key factor toward predicting the recruitment dynamics under the framework of the growth-survival paradigm.

Acknowledgements. We thank T. Yamakawa, Y. Watanabe, T. Sugimito and M. Sano for their critical and constructive comments on earlier drafts of the manuscript. Field sampling in 2001 was supported by I. Mitani, C. Fukawa and Y. Fukawa. The manuscript benefited from the constructive comments of J. Shoji, D. Robert, T. Miller, T. Akamine and 3 anonymous reviewers.

\section{LITERATURE CITED}

Anderson JT (1988) A review of size dependent survival during pre-recruit stages of fishes in relation to recruitment. J Northwest Atl Fish Sci 8:55-66
Bailey KM, Houde ED (1989) Predation on eggs and larvae of marine fishes and the recruitment problem. Adv Mar Biol 25:1-83

Baumann H, Pepin P, Davidson FJM, Mowbray F, Schnack D, Dower JF (2003) Reconstruction of environmental histories to investigate patterns of larval radiated shanny (Ulvaria subbifurcata) growth and selective survival in a large bay of Newfoundland. ICES J Mar Sci 60:243-258

Campana SE (1990) How reliable are growth backcalculations based on otoliths? Can J Fish Aquat Sci 47: $2219-2227$

Campana SE, Jones CM (1992) Analysis of otolith microstructure data. Can Spec Publ Fish Aquat Sci 117:73-100

Chambers RC, Leggett WC (1987) Size and age at metamorphosis in marine fishes: an analysis of laboratory-reared winter flounder (Pseudopleuronectes americanus) with a review of variation in other species. Can J Fish Aquat Sci 44:1936-1947

Chick JH, Van Den Avyle MJ (2000) Effects of feeding ration on larval swimming speed and responsiveness to predator attacks: implications for cohort survival. Can J Fish Aquat Sci 57:106-115

Fuiman LA, Magurran AE (1994) Development of predator defences in fishes. Rev Fish Biol Fish 4:145-183

Fuiman LA, Cowan JH Jr, Smith ME, O'Neal JP (2005) Behavior and recruitment success in fish larvae: variation with growth rate and the batch effect. Can J Fish Aquat Sci 62: $1337-1349$

Grorud-Colvert K, Sponaugle S (2006) Influence of condition on behavior and survival potential of a newly settled coral reef fish, the bluehead wrasse Thalassoma bifasciatum. Mar Ecol Prog Ser 327:279-288

Hare JA, Cowen RK (1997) Size, growth, development, and survival of the planktonic larvae of Pomatomus saltatrix (Pisces: Pomatomidae). Ecology 78:2415-2431

Healey MC (1982) Timing and relative intensity of size-selective mortality of juvenile chum salmon (Oncorhynchus keta) during early sea life. Can J Fish Aquat Sci 39:952-957

Hoey AS, McCormick MI (2004) Selective predation for low body condition at the larval-juvenile transition of a coral reef fish. Oecologia 139:23-29

Houde ED (1987) Fish early life dynamics and recruitment variability. Am Fish Soc Symp 2:17-29

Houde ED (1989) Subtleties and episodes in the early life of fishes. J Fish Biol 35(Suppl A):29-38

Hovenkamp F (1992) Growth-dependent mortality of larval plaice Pleuronectes platessa in the North Sea. Mar Ecol Prog Ser 82:95-101

Lankford TE, Billerbeck JM, Conover DO (2001) Evolution of intrinsic growth and energy acquisition rates. II. Tradeoffs with vulnerability to predation in Menidia menidia. Evolution 55:1873-1881

Leggett WC, DeBlois E (1994) Recruitment in marine fishes: Is it regulated by starvation and predation in the egg and larval stages? Neth J Sea Res 32:119-134

Litvak MK, Leggett WC (1992) Age and size-selective predation on larval fishes: the bigger-is-better hypothesis revisited. Mar Ecol Prog Ser 81:13-24

Meekan MG, Fortier L (1996) Selection for fast growth during the larval life of Atlantic cod Gadus morhua on the Scotian Shelf. Mar Ecol Prog Ser 137:25-37

Miller TJ, Crowder LB, Rice JA, Marschall EA (1988) Larval size and recruitment mechanisms in fishes: toward a conceptual framework. Can J Fish Aquat Sci 45:1657-1670

Munch SB, Conover DO (2003) Rapid growth results in increased susceptibility to predation in Menidia menidia. Evolution 57:2119-2127 
Oozeki Y, Watanabe Y, Kitagawa D (2004) Environmental factors affecting larval growth of Pacific saury, Cololabis saira, in the northwestern Pacific Ocean. Fish Oceanogr 13 (Suppl 1):44-53

Robert D, Castonguay M, Fortier L (2007) Early growth and recruitment in Atlantic mackerel Scomber scombrus: discriminating the effects of fast growth and selection for fast growth. Mar Ecol Prog Ser 37:209-219

Searcy SP, Sponaugle S (2001) Selective mortality during the larval-juvenile transition in two coral reef fishes. Ecology 82:2452-2470

Shoji J, Tanaka M (2006) Growth-selective survival in piscivorous larvae of Japanese Spanish mackerel Scomberomorus niphonius: early selection and significance of ichthyoplankton prey supply. Mar Ecol Prog Ser 321: 245-254

Skajaa K, Fernö A, Folkvord A (2003) Swimming, feeding and predator avoidance in cod larvae (Gadus morhua L.): trade-offs between hunger and predation risk. In: Browman HI, Skiftesvik AB (eds) The big fish bang: Proceedings of the 26th Annual Larval Fish Conference. The Institute of Marine Research, Bergen, Norway, p 105-121

Takahashi M, Watanabe Y (2004) Growth rate-dependent recruitment of Japanese anchovy Engraulis japonicus in

Editorial responsibility: Jon Hare (Contributing Editor), Narragansett, Rhode Island, USA the Kuroshio-Oyashio transitional waters. Mar Ecol Prog Ser 266:227-238

Takasuka A, Aoki I (2006) Environmental determinants of growth rates for larval Japanese anchovy Engraulis japonicus in different waters. Fish Oceanogr 15:139-149

Takasuka A, Aoki I, Mitani I (2003) Evidence of growthselective predation on larval Japanese anchovy Engraulis japonicus in Sagami Bay. Mar Ecol Prog Ser 252:223-238

Takasuka A, Aoki I, Mitani I (2004a) Three synergistic growth-related mechanisms in the short-term survival of larval Japanese anchovy Engraulis japonicus in Sagami Bay. Mar Ecol Prog Ser 270:217-228

Takasuka A, Oozeki Y, Kimura R, Kubota H, Aoki I (2004b) Growth-selective predation hypothesis revisited for larval anchovy in offshore waters: cannibalism by juveniles versus predation by skipjack tunas. Mar Ecol Prog Ser 278: 297-302

Takasuka A, Oozeki Y, Aoki I (2007) Optimal growth temperature hypothesis: Why do anchovy flourish and sardine collapse or vice versa under the same ocean regime? Can J Fish Aquat Sci 64:768-776

Tanaka Y, Satoh K, Iwahashi M, Yamada H (2006) Growthdependent recruitment of Pacific bluefin tuna Thunnus orientalis in the northwestern Pacific Ocean. Mar Ecol Prog Ser 319:225-235

Submitted: February 8, 2006; Accepted: July 15, 2007 Proofs received from author(s): November 13, 2007 